\title{
Differentiation of Mammosomatotrophs in Swine Adenohypophysis
}

\author{
Takahiro Yamaguchi ${ }^{1}$, Yohichi Ide ${ }^{2}$, Takahiro Sato ${ }^{1}$, Takuya Satoh ${ }^{1}$ and \\ Masatoshi Matsuzaki ${ }^{3}$ \\ 'Laboratory of Functional Morphology, Department of Animal Production Science, Graduate School of Agricultural \\ Science, Tohoku University, Sendai 981-8555, ${ }^{2}$ Pharmaceutical Development Laboratory, Kirin Brewery Co., Ltd., \\ Maebashi 371-0037 and ${ }^{3}$ Kyushu National Agricultural Experiment Station, Kumamoto 861-1102
}

Received March 11, 1999; accepted May 13, 1999

\begin{abstract}
The existence and distribution of mammosomatotrophs (MS cells) containing growth hormone (GH) and prolactin (PRL) were detailed in swine adenohypophysis. MS cells were positively identified and were first recognized in the adenohypophysis of fetuses with $33.0 \mathrm{~cm}$ in body length, when $\mathrm{GH}$ cells existed earlier and PRL cells occurred. The proportion of MS cells transiently increased in the glands of three month-old females and were densely populated in the fore ventral (FV) and the hind ventral (HV) region except for the zona tuberalis (ZT). The distribution was similar to $\mathrm{GH}$ cells and PRL cells. MS cells were divided into three subtypes by the intracellular intensity of both GH and PRL stainings. Type I MS cells which were strongly stained with anti-GH antiserum, constituted $100 \%$
\end{abstract}

of MS cells in fetuses and the proportion decreased with age in females. Type II MS cells which were evenly stained with both anti-GH and PRL antisera were detected in all animals except for fetuses, and were proportioned moderately. Type III MS cells which contained more PRL than GH existed predominately in three and six month-old females, castrated males and aged males. The findings indicated that an amount of GH and PRL within MS cells was changeable in response to physiological conditions. The results suggest that $\mathbf{G H}$ cells may transform into PRL cells, with the MS cell acting as an intermediate cell in swine adenohypophysis, and that the GH and PRL in MS cells are synthesized synchronously or asynchronously according to the secretory activities.

Key words: Swine adenohypophysis, Mammosomatotrophs, Distribution, Differentiation, Functional heterogeneity

\section{Introduction}

Growth hormone $(\mathrm{GH})$ and prolactin (PRL) are protein hormones that are produced in corresponding specific pituitary secretory cells, somatotrophs (GH cells) and mammotrophs (PRL cells). Recently, existence of a new cell type that secretes both GH and PRL was first described in the adenohypophysis of adult male rats by using a reverse haemolytic plaque assay [7]. The bihormonal cells were ascertained immunocytochemically in intact adult rats and designated as mammosomatotrophs or somatomammotrophs (MS cells) [24]. The existence of MS cells has been reported in rats [17, 22, 24, 25], the musk shrew [17], bats [18], mice [29,30], the rhesus monkeys [1],

Correspondence to: Takahiro Yamaguchi, Ph.D., Laboratory of Functional Morphology, Department of Animal Production Science, Graduate School of Agricultural Science, Tohoku University, 1-1 Tsutsumidori Amamiyamachi Aoba-ku, Sendai 981-8555, Japan. humans [21, 23], bovine [9, 12], sheep [37, 38] and goats [31]. It is now proposed that possible functions of MS cells are as transitional cells for the conversion of $\mathrm{GH}$ cells to PRL cells $[2,3,14,26,27]$, or as progenitor cells for GH cells and PRL cells [23]. However, the developmental and functional significance of MS cells is not fully understood, although their occurrence is closely related to the differentiation of GH cells and PRL cells $[5,16]$.

In swine adenohypophysis, Dachux reported that no one cell can synthesize and store both GH and PRL under normal physiological conditions [6]. Thereafter, surprisingly, no information is available about the existence and distribution of MS cells in swine adenohypophysis. Since MS cells are occasionally present throughout adenohypophysis in sheep [37, 38], mice [29] and goats [31], further extensive and precise observations are needed to conclude if MS cells exist or not in swine adenohypophysis. The present study is focussed on the existence and distribution of MS cells in swine adenohypophysis, and on 
the mutual relationship of MS cells, and GH cells and PRL cells for differentiation.

\section{Materials and Methods}

\section{Animals}

Swine of three-way crosses of Duroc and Landrace $x$ Large white F1 sows were used in the present study. The swine consisted of three female fetuses of $17.5 \mathrm{~cm}$ and $33 \mathrm{~cm}$ body lengths, three females of three months-old, three females and three castrated males of six months-old, and three boars of two or three years-old. The castration of male swine was carried out on day $35-45$ postpartum.

\section{Tissue preparation}

The pituitary glands were freshly removed and bisected at the midsagittal plane. The tissues were removed from three regions of the midsagittal plane, the fore ventral (FV) and hind ventral (HV) region, and the zona tuberalis (ZT), and diced into pieces about $1 \mathrm{~mm}^{3}$. The pieces were fixed in Zamboni's solution [34] for $6 \mathrm{hr}$ at $4^{\circ} \mathrm{C}$, and post-fixed in a $1 \%$ osmium tetroxide solution for $1 \mathrm{hr}$ at $4^{\circ} \mathrm{C}$. After the fixation, all tissue blocks were rinsed thoroughly with a cacodylate buffer $(0.1 \mathrm{M}$, pH 7.4), dehydrated in a graded series of ethanol and embedded in Spurr's resin.

\section{Immunohistochemistry}

A couple of serial sections, consisting of $0.5 \mu \mathrm{m}$ sections, were cut from each block by an ultramicrotome (Ultracut S, Reichert-Nissei, Wien, Austria). The sections were mounted on glass slides previously coated with polyL-lysine and treated with sodium methoxide for $4 \mathrm{~min}$ to remove the resin. The sections were incubated in a $0.05 \%$ saponin solution for $20 \mathrm{~min}$, and then washed with PBS. After the treatment of normal goat serum for $20 \mathrm{~min}$, one of the serial sections was incubated with anti-porcine $\mathrm{GH}$ rabbit antiserum (1:3,200; Biogenesis, Poole, England), and the other with anti-porcine PRL rabbit antiserum $\left(1: 3,200\right.$; Biogenesis) for $14 \mathrm{hr}$ at $4^{\circ} \mathrm{C}$. After washing three times in PBS, the immunoreactive cells were visualized by immunogold silver staining (IGSS) [15]. Briefly, the sections were incubated with gold-labeled anti-rabbit IgG antibody ( $5 \mathrm{~nm}, 1: 60$; BioCell International, Cardiff, England) for $1 \mathrm{hr}$, and immersed in physical developer for $45 \mathrm{~min}$ according to the method of Fujimori and Nakamura [8]. After washing in distilled water, the counterstain was performed with Carazzi's heamatoxylin. To investigate the specificity of GH and PRL immunoreactions, the primary antibody was omitted or replaced by irrelevant rabbit IgG at about the same protein concentration in which the specificity was ascertained by a total loss of the staining.

\section{Percentages of MS cells}

The photomicrographs were obtained from the FV, HV and ZT of several sections at $\times 400$. The number of cells that contained only GH or PRL, and both GH and PRL, was counted and the percentage (immunoreactive cells/total cells $\times 100$ ) was calculated. A total of 2,000 to 20,000 cells in each region was observed on several photomicrographs.

\section{Statistical analysis}

The statistical significances of difference were evaluated by Student's $t$ test for the difference of cell frequency, and were determined by an Analysis of Variance followed by Tukey's Multiple Range Test for the difference among each region.

\section{Results}

\section{Existence and distribution of MS cells}

In swine adenohypophysis, numerous cells were immunostained with each anti-GH and anti-PRL antiserum. GH cells and PRL cells were first detected in fetuses of $17.5 \mathrm{~cm}$ and $33.0 \mathrm{~cm}$ body lengths, respectively. GH cells increased in number until just before delivery. The occurrence of MS cells was precisely evaluated on two serial sections. MS cells were first identified in fetuses of $33.0 \mathrm{~cm}$ in body length on about the 105th day of gestation in swine (Fig. 1), and occasionally appeared as a group of two or three cells. In the fetus adenohypophysis, $\mathrm{GH}$ cells existed predominantly over PRL cells. In three monthold females, the existence of MS cells was significantly greater in FV and HV where GH cells and PRL cells were densely populated, but the proportion was much lower than that of GH cells and PRL cells (Table 1). In ZT where GH cells and PRL cells were less frequent, the proportion of MS cells was very low (Table 1). MS cells were mainly solitarily distributed, and occasionally grouped in the cell clusters of GH cells and PRL cells.

\section{Changes of MS cell proportion}

The proportion of MS cells was compared in the FV region where the numeral density was the highest in female adenohypophysis of three-months old (Table 2). MS cells were detected at the rate of $0.2 \%$ in female fetuses with a $33 \mathrm{~cm}$ body length, increased to $5.5 \%$ in three month-old females and decreased to $1.5 \%$ in six month-old females. The proportion was still lower in aged boars. At six months-old, the proportion of MS cells in castrated males was significantly greater than that of females (Table 2).

\section{Functional heterogeneity of MS cells}

In swine adenohypophysis, some MS cells were evenly stained with both anti-GH and anti-PRL antisera, but other cells were heterogeneously immunostained by only one of them. To investigate the mutual relationship between an amount of intracellular GH and PRL, and the function of MS cells, the cells were divided into three subtypes by the relative intensity of $\mathrm{GH}$ and PRL immunostainings. Type I MS cells were immunoreactive for anti-GH antiserum stronger than anti-PRL antiserum 


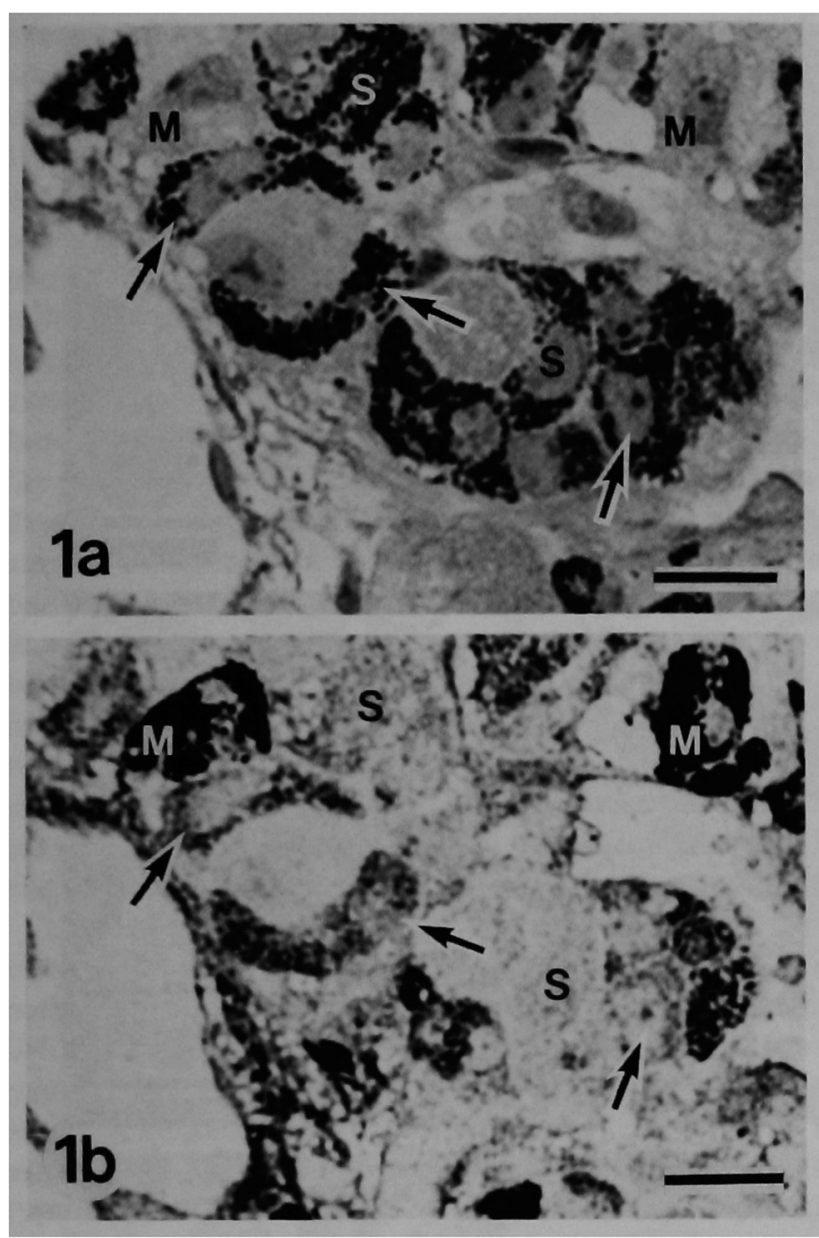

Fig. 1. A couple of serial sections of fetal adenohypophysis with $33 \mathrm{~cm}$ body lengths immunostained with $\mathrm{GH}$ (a) and PRL (b) antiserum. MS cells immunoreactive for both antisera are distinguishable as Type I cells by the predominance of GH staining (arrows). $\mathrm{S}$ and $\mathrm{M}$ show $\mathrm{GH}$ cells and PRL cells, respectively. $\mathrm{Bar}=10 \mu \mathrm{m}$.

(Fig. 1). All MS cells in fetuses were Type I MS cells, which proportionally decreased in females with age (Table 2). Type II MS cells were evenly immunostained with both anti-GH and anti-PRL antisera and were detected in three and six month-old females, castrated males and aged males except for fetuses (Table 2). A large number of Type II MS cells were strongly immunostained with both

Table 1. Distribution of MS cells, GH cells and PRL cells in three different regions of swine adenohypophysis.

\begin{tabular}{ccrc}
\hline Region & MS cells & GH cells & PRL cells \\
\hline FV & $5.5 \pm 1.5^{\mathrm{b}}$ & $25.7 \pm 4.7^{\mathrm{b}}$ & $44.9 \pm 5.5^{\mathrm{b}}$ \\
HV & $2.7 \pm 0.8^{\mathrm{b}}$ & $28.2 \pm 3.8^{\mathrm{b}}$ & $34.5 \pm 6.4^{\mathrm{b}}$ \\
ZT & $0.8 \pm 0.4^{\mathrm{a}}$ & $8.7 \pm 1.7^{\mathrm{a}}$ & $13.8 \pm 3.4^{\mathrm{a}}$ \\
\hline
\end{tabular}

Values are mean percentages \pm S.D. of adenohypophysial cells from three animals of three months-old. Significantly different means $(p<0.05)$ are identified by different letters in same column.
Table 2. Changes of MS cells and their subtypes in swine adenohypophysis.

\begin{tabular}{|c|c|c|c|c|}
\hline \multirow{2}{*}{ Animals } & \multirow{2}{*}{$\begin{array}{c}\% \text { of } \\
\text { MS cells }\end{array}$} & \multicolumn{3}{|c|}{$\%$ of MS cell subtypes } \\
\hline & & I & II & III \\
\hline \multicolumn{5}{|l|}{ Fetuses } \\
\hline (17.5 cm body length) & 0.0 & 0.0 & 0.0 & 0.0 \\
\hline \multicolumn{5}{|l|}{ Fetuses } \\
\hline ( $33.0 \mathrm{~cm}$ body length) & $0.2^{\mathrm{a}}$ & 100.0 & 0.0 & 0.0 \\
\hline \multicolumn{5}{|l|}{ Females } \\
\hline ( 3 months-old) & $5.5^{\mathrm{c}}$ & 13.1 & 33.8 & 53.2 \\
\hline \multicolumn{5}{|l|}{ Females } \\
\hline (6 months-old) & $1.5^{\mathrm{b}}$ & 1.5 & 34.3 & 64.2 \\
\hline \multicolumn{5}{|l|}{ Castrated males } \\
\hline (6 months-old) & $5.8^{\mathrm{c}}$ & 14.4 & 29.2 & 56.4 \\
\hline \multicolumn{5}{|l|}{ Boar } \\
\hline (2-3 years-old) & $0.7^{\mathrm{a}}$ & 16.7 & 20.8 & 62.5 \\
\hline
\end{tabular}

Significantly different means $(p<0.05)$ are identified by different letters in \% of MS cells.

antisera (Fig. 2) and these cells frequently existed in six month-old females and aged males. Type II MS cells which were weakly immunostained with both antisera were relatively more commom in 3 month-old females and castrated males (Fig. 3). Type III MS cells which were more heavily immunostained by anti-PRL antiserum than antiGH antiserum (Fig. 4), predominated in three and six month-old females, castrated males and aged males (Table 2). The fluctuation of GH and PRL in MS cells indicated that the cells are functionally heterogeneous depending upon physiological conditions. However, in some cases, especially in six month-old females, it was hard to clearly distinguish Type III MS cells because of the scant staining of $\mathrm{GH}$.

\section{Discussion}

The present study initially demonstrated the substantial existence of MS cells in swine adenohypophysis by two serial sections combined with IGSS methods. Dacheux, however, did not succeed in immunological detection of MS cells under normal physiological conditions for swine adenohypophysis [6]. The experiments were carried out with electron immunocytochemical methods, which is insufficient to observe the entire adenohypophysial constituents. Since MS cells were low in number and their existence changed regionally and age-dependently in swine adenohypophysis, a difference between our findings and the above mentioned work may be partly due to the difference in methods used to identity MS cells.

The reliable identification of MS cells in the present study revealed the differential distribution in the three regions of swine adenohypophysis. The proportion of MS cells was higher in the region where GH cells and PRL 

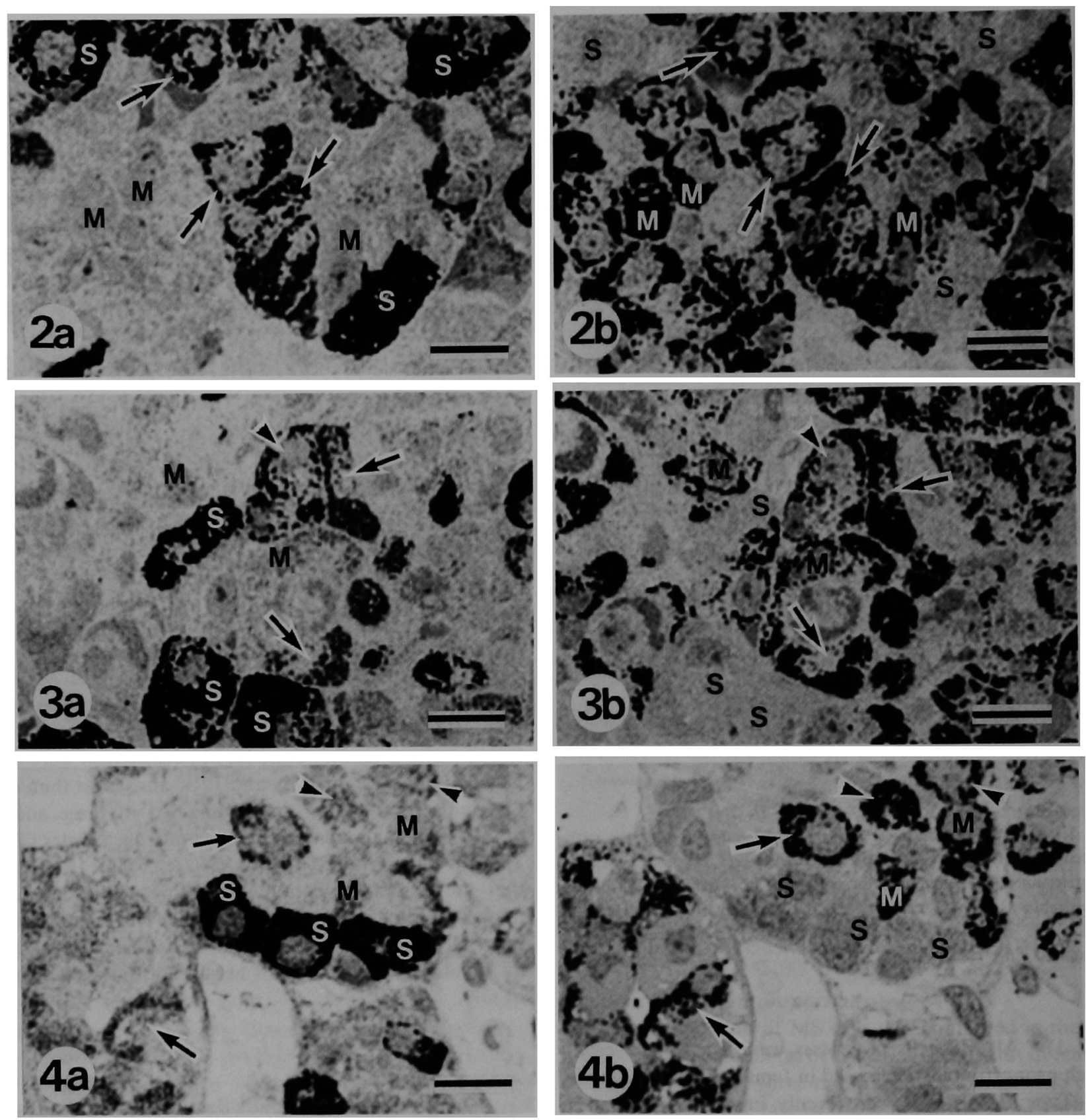

Fig. 2. Type II MS cells which are strongly immunostained by both GH (a) and PRL (b) antisera in female adenohypophysis of six months-old (arrows). The cells exist adjacently to GH cells (S) and PRL cells (M). Bar $=10 \mu \mathrm{m}$.

Fig. 3. Type II MS cells which are weakly immunostained by both GH (a) and PRL (b) antisera in female adenohypophysis of three monthsold (arrowhead). The cells occasionally appear together with other types of MS cells (arrows) within a cluster of GH cells (S) and PRL cells (M). $B a r=10 \mu \mathrm{m}$.

Fig. 4. Type III MS cells which are immunostained by PRL antiserum (b) stronger than GH antiserum (a) in castrated-male adenohypophysis of six months-old (arrows). In some PRL cells, GH is scantily immunostained (arrowheads). S and M show GH cells and PRL cells, respectively. $B a r=10 \mu \mathrm{m}$.

cells were densely populated, and was lower in ZT which consists of almost only basophils and chromophobes, but not acidophils [40]. In addition, the occurrence of MS cells was later than for GH cells, and was almost simultaneous with PRL cells during the fetal period. MS cell distribution similar to GH and PRL cells suggests that their occurrence may be closely associated with the cytogenesis of GH and PRL cells.

Although several researchers have reported the proportional differences of MS cells for ages and sexes [7, $18,20]$, the data of the relative proportion cannot be directly compared, because the mode of data description is 
different. Kineman et al. reported that pituitary cell cultures contained fewer MS cells in gonad-intact males when compared with castrated males in bovine adenohypophysis [19]. In swine adenohypophysis, the proportion of MS cells in castrated males was more than that for gonadintact females of the same age. From these findings, it is supposed that the changes of hormonal milieu after castration correlate with the induction of MS cells, although the proportional changes of MS cells between the different sexes remains unclear. On the other hand, MS cells showed an age-related decline in swine adenohypophysis. The proportion of PRL cells, however, increased with age (data not shown). Shinkai et al. [31] reported that the number of MS cells at 21 months old increased to more than five times the average of 12-13 months old in female rat adenohypohpysis, and the number of PRL cells also steadily increased with age by a flow cytometric study. Since GH and PRL within the MS cells are of a variety owing to the difference in physiological states of the animals, it is likely that some MS cells are classified in the category of PRL cells by an immunocytochemical method when the GH within MS cells is scanty.

The IGSS method has been developed to detect low levels of fixed antigens in tissue sections [11, 32]. This method enabled us to accurately observe the intracellular GH and PRL within MS cells on the sections. The subtypes of MS cells uniquely changed with age in female swine. Unexpectedly, MS cells in fetuses were all Type I cells. Type III MS cells age-dependently increased as Type I MS cells decreased. In regard to the reciprocal changes of GH and PRL within MS cells, there is little available information. Ishibashi and Shiino [18], however, have reported that MS cells show remarkable seasonal fluctuations, and the granules with $\mathrm{GH}$ and/or PRL proportionally change throughout the reproductive cycle in the female Japanese house bat. They suggested that the MS cell itself gradually enhanced its ability to produce PRL rather than GH, and ultimately changed into a pure $P R L$-producing cell. Considering these findings, it is speculated that the subtypes of MS cells in swine adenohypophysis result in functional heterogeneity under different secretory activities although the localization of $\mathrm{GH}$ and PRL within the same granules remains to be investigated.

The mechanism responsible for cytogenesis of MS cells in swine adenohypophysis is not fully understood. Our investigations showed that 1) MS cells occurred almost simultaneously with PRL cells while GH cells preexisted, 2) MS cells are regionally distributed similar to GH cells and PRL cells and 3) the hormone contents of MS cells changed from GH to PRL with age. From these findings, it is conceivable that MS cells originate in GH cells that preexisted in swine adenohypophysis. The possibility that MS cells are a transitional stage of conversion from GH cells to PRL cells has been reported during the embryonic period $[19,36,39]$. The increase in MS cells in mice transgenic for GHRH suggests that the generation of
MS cells is connected to the differentiation of GH cells [33]. Using the thymidine kinase obliteration system, Borrelli et al. [3] reported that both GH cells and PRL cells derive from a common $\mathrm{GH}$-expressing stem $\mathrm{GH}$ cell, which terminally differentiates into GH and PRL cell populations in transgenic mice. These findings support a possible transformation of GH cells into PRL cells, with MS cells acting as an intermediate cell in swine adenohypophysis as previously described in the adenohypophysis of rats $[5,13,26,35]$, humans $[10]$ and bats [18].

In conclusion, we identified MS cells producing both $\mathrm{GH}$ and PRL in swine adenohypophysis, and revealed that the frequency of occurrence of MS cells changes relatively under normal physiological conditions. The proportional divergence in MS cells suggests that the hormonal milieu of adenohypophysis plays an important role in cell differentiation. A full understanding of the mechanism of how MS cells functionally correlate to GH cells and PRL cells will require additional investigation by an accurate localization of GH and PRL within the secretory granules of MS cells .

\section{Acknowledgments}

This investigation was supported by grants from the Ito Foundation, Tokyo, Japan.

\section{References}

1. Bethea, C. L.: Estrogen action on growth hormone in pituitary cell cultures from adult from juvenile macaques. Endocrinology 129; 2110-2118, 1991.

2. Boockfor, F. R., Hoeffer, J. P. and Frawley, L. S.: Analysis by plaque assay of $\mathrm{GH}$ and prolactin release from individual cells in cultures of male pituitaries. Evidence for functional heterogeneity within rat mammotroph and somatortoph populations. Neuroendocrinology 42; 64-70, 1986.

3. Borrelli, E., Heyman, R. A., Arias, C., Sawchenko, P. E. and Evans, P.M.: Transgenic mice with inducible dwarfism. Nature 339; 538-541, 1989.

4. Boockfor, F. R., Hoeffler, P. and Frawley, L. S.: Estradiol induces a shift in cultured cells that release prolactin or growth hormone. Am. Physiol. Soc. 250; E103-E105, 1986.

5. Chomczynski, P., Brar, A. and Frohman, L. A.: Growth hormone synthesis and secretion by a somatomammotroph cell line derived from normal adult pituitary of the rat. Endocrinology 123; 2276-2283, 1988.

6. Dacheux, F.: Ultrastructural immunocytochemical localization of prolactin and growth hormone in the porcine pituitary. Cell Tissue Res. 207; 277-286, 1980.

7. Frawley, L. S., Boockfor, F. R. and Hoeffler, J. P.: Identification by plaque assays of a pituitary cell type that secretes both growth hormone and prolactin. Endocrinology 116; 734-737, 1985.

8. Fujimori, O. and Nakamura, M.: Protein A-silver staining method for light microscopic immunochemistry. Arch. Histol. Jap. 48; 449-454, 1985.

9. Fumagalli, G. and Zanini, A.: In cow anterior pituitary, growth hormone and prolactin can be packed in separate granules of the same cell. J. Cell Biol. 100; 2019-2024, 1985.

10. Goluboff, I. G. and Ezin, C.: Effect of pregnancy on the 
somatotropic and the prolactin cell of human adenohypophysis. J. Clin. Endocrinol. 29; 1533-1542, 1969.

11. Hacker, G. W., Springgalli, D. R., Van Noorden, S., Bishop, A. E., Grimelius, L. and Polak, J. M.: The immunogold staining method: a powerful tool in histopathology. Virchows Arch. [A] 406; 449-461, 1985.

12. Hashimoto, S., Fumagall, G., Zanini, A. and Meldolesi, J.: Sorting of three secretory proteins to distinct secretory granules in acidophilic cells of cow anterior pituitary. J. Cell Biol. 105; 1579-1586, 1987.

13. Ho, K. Y., Thorner, M. O., Kreig, R. J., Lau, S. K., Sinha, Y. N., Johnson, M. L., Leong, D. A. and Evans, W. S.: Effect of gonadal steroids on somatotroph function in the rat: analysis by the reverse haemolytic plaque assay. Endocrinology 123; 1405-1411, 1988.

14. Hoeffler, J. P., Boockfor, F. R. and Frawley, L. S.: Ontogeny of prolactin cells in neonatal rats: initial prolactin secretors also release growth hormone. Endocrinology 117; 187-195, 1985.

15. Holgate, S. C., Jackson, P., Cowen, N. P. and Bird, C. C.: Immunogold-silver staining: new method of immunostaining with enhanced sensitivity. J. Histochem. Cytochem. 31; 938944, 1983.

16. Inoue, $\mathrm{K}$. and Sakai, T.: Conversion of growth hormonesecreting cells into prolactin-secreting cells and its promotion by insulin and insulin-like growth factor-1 in vitro. Exp. Cell Res. 195; 53-58, 1991.

17. Ishibashi, T. and Shiino, M.: Co-localization pattern of growth hormone $(\mathrm{GH})$ and prolactin $(\mathrm{PRL})$ within the anterior pituitary cells in the female rat and female musk shrew. Anat. Rec. 223; 185-193, 1989.

18. Ishibashi, $T$. and Shiino, M.: Subcellular localization of prolactin in the anterior pituitary cells of the female Japanese house bat, pipistrellus abramus. Endocrinology 124; 1056$1063,1989$.

19. Kineman, R. D., Faught, W. J. and Frawley, L. S.: Mammosomatotropes are abundant in bovine pituitaries: influence of gonadal status. Endocrinology 128; 2229-2233, 1991.

20. Leong, D., Leu, S., Sinha, Y., Kaiser, D. and Thorner, M.: Enumeration of lactotropes and somatotropes among male and female pituitary cells in culture: evidence in favor of a mammosomatotrope subpopulation in rat. Endocinology 116; 1371-1378, 1985.

21. Lloyd, R. V., Anagnostou, D., Cano, M., Barkan, A. L. and Chandler, W.F.: Analysis of mammosomatotropic cells in normal and neoplastic human pituitary tissues by the reverse hemolytic plaque assay and immunocytochemistry. J. Clin. Endocrinol. Metab. 66; 1103-1110, 1988.

22. Losinski, N. E., Horvath, E. and Kovacs, K.: Double-labeling immunogold electron-microscopic study of hormonal colocalization in nontumorous and adenomatous rat pituitaries. $\mathrm{Am}$. J. Anat. 185; 236-243, 1989.

23. Mulchahey, J. J. and Jaffe, R. B.: Detection of a potential progenitor cell in the human fetal pituitary that secretes both growth and prolactin. J. Clin. Endocrinol. Metab. 66; 24-32, 1988.

24. Nikitovitch-Winer, M. B., Atkin, J. and Maley, B. E.: Colocalization of prolactin and growth hormone within specific adenohypophyseal cells in male, female, and lactating female rats. Endocrinology 121; 625-630, 1987.

25. Pasolli, H. A., Torres, A. I. and Aoki, A.: The mammosomatotrophs: a transitional cell between growth hormone and prolactin producing cells? An immunocytochemical study. Histochemistry 102; 287-296, 1994.

26. Porter, E. T., Hill, J. B., Willes, D. C. and Frawley, L. S.: Is the mammosomatotrope a transitional cell for the functional interconversion of growth hormone- and prolactin-secreting cells? suggestive evidence from virgin, gestating, and lactating rats. Endocrinology 127; 2789-2794, 1990.

27. Porter, T. E., Wiles, C. D. and Frawley, L. S.: Evidence for bidirectional interconversion of mammotropes and somatotropes: rapid reversion of acidophilic cell types to pregestational proportions after weaning. Endocrinology 129; 1215-1220, 1991.

28. Sanchez, J., Navarro, J. A., Bernabe, A., Gomez, S., Garces, B. and Gomez, M. A.: Identification of somatomammotroph cells in lactating goats (Capra hircus) by fluorescence and immunogold techniques. Acta Anat. 149; 39-45, 1994.

29. Sasaki, F. and Iwama, Y.: Sex difference in prolactin and growth hormone cells in mouse adenohypophysis: stereological, morphometric, and immunohistochemical studies by light and electron microscopy. Endocrinology 123; 905912,1988

30. Sasaki, F. and Iwama, Y.: Two type of mammosomatotropes in mouse adenohypophysis. Cell Tissue Res. 256; 645-648, 1989.

31. Shinkai, T., Sakurai, Y. and Ooka, H.: Age-related changes in the numbers of mammotrophs, somatotrophs and mammosomatotrophs in the anterior pituitary gland of female rats: $A$ flow cytometric study. Mech. Aging Dev. 83; 125-131, 1995.

32. Spingall, D. R., Hacker, G. W., Grimelius, L. and Polak, J. M.: The potential of the immunogold-silver staining method for paraffin sections. Immunochemistry 81; 603-608, 1984.

33. Stefaneanu, L., Kovacs, K., Horvath, E., Asa, S. L., Losinski, N. E., Billestrup, N., Price, J. and Vale, W.: Adenohyphphysial changes in mice transgenic for human growth-hormone releasing factor. A histological, immunohistochemical, and electron microscopic investigation. Endocrinology 125; 2710 2718, 1989.

34. Stefanini, M., De Martio, C. and Zamboni, C.: Fixation of ejaculated spermatozoa for electron microscopy. Nature 216; 173-174, 1967.

35. Stratmann, E. I., Ezrin, C. and Sellers, E. A.: Estrogen-induce transformation of somatotrophs into mammotrophs in the rat. Cell Tissue Res. 152; 229-238, 1970.

36. Takahashi, S.: Heterogenity and development of somatotrophs and mammotrophs in the rat. Zool. Sci. 9; 901-924, 1992.

37. Thorpe, J. R. and Wallis, M.: Immunocytochemical and morphometric studies of mammotrophs, somatotrophs and somatomammotrophs in sheep pituitary cell cultures. J. Endocrinol. 129; 417-422, 1990.

38. Thorpe, J. R., Ray, K. P. and Wallis, M.: Occurrence of rare somatomammotrophs in ovine anterior pituitary tissue studied by immunogold labelling and electron microscopy. J. Endocrinol. 124; 67-73, 1989.

39. Vidal, S., Ruiz-Navarro, A., Gracia-Navarro, F. and Moya, L.: Presence of mammosomatotropic (MS) cells in mink (Mustela vison) adenohypophysis. Tissue Cell 21; 79-84, 1995.

40. Yamaguchi, T., Hoshino, T. and Tamate, H.: Functional morphology in the anterior pituitary gland. I. The cell types and distribution in the anterior pituitary gland of pigs of different sexes and ages. Tohoku J. Agri. Res. 24; 41-53, 1973. 